\title{
Uptake and metabolic effects of 3-iodothyronamine in hepatocytes
}

\section{Sandra Ghelardoni, Grazia Chiellini, Sabina Frascarelli, Alessandro Saba and Riccardo Zucchi}

Dipartimento di Patologia Chirurgica Medica Molecolare e dell'Area Critica, University of Pisa, Via Roma 55, 56126 Pisa, Italy
Correspondence should be addressed to G Chiellini Email g.chiellini@bm.med.unipi.it

\begin{abstract}
3-lodothyronamine $\left(T_{1} A M\right)$ is an endogenous relative of thyroid hormone with profound metabolic effects. In different experimental models, $T_{1} A M$ increased blood glucose, and it is not clear whether this effect is entirely accounted by changes in insulin and/or glucagone secretion. Thus, in the present work, we investigated the uptake of $T_{1} A M$ by hepatocytes, which was compared with the uptake of thyroid hormones, and the effects of $T_{1} A M$ on hepatic glucose and ketone body production. Two different experimental models were used: HepG2 cells and perfused rat liver. Thyronines and thyronamines (TOAMs) were significantly taken up by hepatocytes. In HepG2 cells exposed to $1 \mu \mathrm{M} \mathrm{T} \mathrm{T}_{1} \mathrm{AM}$, at the steady state, the cellular concentration of $\mathrm{T}_{1} \mathrm{AM}$ exceeded the medium concentration by six- to eightfold. Similar accumulation occurred with 3,5,3'-triiodothyronine and thyroxine. Liver experiments confirmed significant $\mathrm{T}_{1} \mathrm{AM}$ uptake. $\mathrm{T}_{1} \mathrm{AM}$ was partly catabolized and the major catabolites were 3-iodothyroacetic acid (TA1) (in HepG2 cells) and TOAM (in liver). In both preparations, infusion with $1 \mu \mathrm{M} \mathrm{T}{ }_{1} \mathrm{AM}$ produced a significant increase in glucose production, if adequate gluconeogenetic substrates were provided. This effect was dampened at higher concentration $(10 \mu \mathrm{M})$ or in the presence of the amine oxidase inhibitor iproniazid, while TA1 was ineffective, suggesting that $\mathrm{T}_{1} \mathrm{AM}$ may have a direct gluconeogenetic effect. Ketone body release was significantly increased in liver, while variable results were obtained in HepG2 cells incubated with gluconeogenetic substrates. These findings are consistent with the stimulation of fatty acid catabolism, and a shift of pyruvate toward gluconeogenesis. Notably, these effects are independent from hormonal changes and might have physiological and pathophysiological importance.
\end{abstract}

\author{
Key Words \\ thyronamines \\ - hepatocytes \\ - metabolism \\ - glucose production
}

\section{Introduction}

3-Iodothyronamine $\left(\mathrm{T}_{1} \mathrm{AM}\right)$ is an endogenous relative of thyroid hormone, which is able to produce acute functional effects (Scanlan et al. 2004, Piehl et al. 2011). Recent advances in the quantitative analysis of $\mathrm{T}_{1} \mathrm{AM}$ using methods based on HPLC coupled to tandem mass spectrometry (MS/MS) have shown that $\mathrm{T}_{1} \mathrm{AM}$ can be detected in blood and tissues derived from rodents and humans, and that in several rat tissues, including heart,
Journal of Endocrinology (2014) 221, 101-110 liver, kidney, skeletal muscle, and stomach, $\mathrm{T}_{1} \mathrm{AM}$ concentration is greater than 3,5, $3^{\prime}$-triiodothyronine $\left(\mathrm{T}_{3}\right)$ and thyroxine $\left(\mathrm{T}_{4}\right)$ concentration (Saba et al. 2010, Galli et al. 2012). Although structural similarities between $\mathrm{T}_{4}$ and $\mathrm{T}_{1} \mathrm{AM}$ have led to the hypothesis that $\mathrm{T}_{1} \mathrm{AM}$ is produced in the peripheral tissues by $\mathrm{T}_{4}$ deiodination and decarboxylation, the biosynthetic origin of $\mathrm{T}_{1} \mathrm{AM}$ remains an open issue. Serum analysis of thyroid cancer 
patients treated with $\mathrm{T}_{4}$ (Hoefig et al. 2011) provided evidence for extrathyroidal $\mathrm{T}_{1} \mathrm{AM}$ production, and limited $\mathrm{T}_{1} \mathrm{AM}$ formation was observed in cardiomyocytes incubated with $\mathrm{T}_{3}$ (Saba et al. 2010). On the other hand, a recent study has revealed that $T_{1} A M$ is not an extrathyroidal metabolite of $\mathrm{T}_{4}$, and is produced by a process that requires the same biosynthetic factors necessary for $\mathrm{T}_{4}$ synthesis, namely the sodium-iodide symporter and thyroperoxidase (Hackenmueller et al. 2012).

The molecular target(s) of $\mathrm{T}_{1} \mathrm{AM}$ are largely unknown. In vitro studies provided evidence that $\mathrm{T}_{1} \mathrm{AM}$ can activate with high-affinity $\mathrm{G}$ protein-coupled receptors, including trace amine-associated receptor 1 (Scanlan et al. 2004, Zucchi et al. 2006) and possibly $\alpha 2$-adrenoceptors (Regard et al. 2007). In addition to these receptors, $\mathrm{T}_{1} \mathrm{AM}$ also interacts with plasma membrane and vesicular biogenic amine transporters (Snead et al. 2007) as well as different mitochondrial targets (Venditti et al. 2011, Cumero et al. 2012).

Administration of exogenous $\mathrm{T}_{1} \mathrm{AM}$ and other thyronamines (TOAMs) produced functional effects that showed a rapid onset and were often opposite to those induced by $\mathrm{T}_{3}$ (Liggett 2004, Weatherman 2007). In rodents, i.p. $\mathrm{T}_{1} \mathrm{AM}$ injection rapidly induced hypothermia, decreased cardiac function and decreased the respiratory quotient, suggesting a shift from primarily carbohydrate to predominantly lipid utilization (Scanlan et al. 2004, Chiellini et al. 2007, Braulke et al. 2008). Recent results from NMR-based metabolomics and breath studies have shown that chronic $\mathrm{T}_{1} \mathrm{AM}$ exposure induced a rapid increase in lipid mobilization, followed after a few days by increased protein breakdown (Haviland et al. 2013). $\mathrm{T}_{1} \mathrm{AM}$-treated mice showed continued reduction in body weight, independent of food consumption, and after $\mathrm{T}_{1} \mathrm{AM}$ withdrawal they regained only $1.8 \%$ of the lost weight in the following 2 weeks. Intracerebroventricular (i.c.v.) injection of $\mathrm{T}_{1} \mathrm{AM}$ modified hormone secretion, food intake, and memory acquisition (Dhillo et al. 2009, Klieverik et al. 2009, Manni et al. 2012, 2013).

$\mathrm{T}_{1} \mathrm{AM}$ effects were not linearly related to the dosage and depended on the animal species and administration route (Dhillo et al. 2009, Klieverik et al. 2009, Manni et al. 2012). The response to $T_{1} A M$ may also be affected by its complex metabolism, which includes oxidative deamination (to 3-iodothyroacetic acid, TA1), deiodination (to TOAM), sulfation (to $\mathrm{O}$-sulfonate- $\mathrm{T}_{1} \mathrm{AM}$ ), acetylation (to $\mathrm{N}$-acetyl$\mathrm{T}_{1} \mathrm{AM}$ ), and glucuronidation (to $\mathrm{T}_{1} \mathrm{AM}$-glucuronide) (Wood et al. 2009, Hackenmueller \& Scanlan 2012).

Among its metabolic effects, $\mathrm{T}_{1} \mathrm{AM}$ has been reported to produce hyperglycemia (Regard et al. 2007,
Klieverik et al. 2009). Notably, hyperglycemia occurs after administration of relatively low doses of exogenous $\mathrm{T}_{1} \mathrm{AM}$, producing changes in tissue concentration of about one order of magnitude (Manni et al. 2013). In addition a clinical investigation performed in a small series of patients revealed that serum $\mathrm{T}_{1} \mathrm{AM}$ concentration was significantly correlated with HbAlc, and significantly increased in a subgroup of diabetic patients (Galli et al. 2012). Therefore, the effects of $T_{1} A M$ on glucose metabolism might have physiological and pathophysiological relevance. The mechanism of this effect is largely unknown. As hyperglycemia was observed after i.c.v. injection, it was originally attributed to central regulation of endocrine function, namely stimulation of glucagon secretion and/or inhibition of insulin secretion (Klieverik et al. 2009). However, it was recently observed that even after i.c.v. injection, a significant increase in plasma $\mathrm{T}_{1} \mathrm{AM}$ was produced (Manni et al. 2012), and the possible occurrence of peripheral effects on glucose metabolism has been suggested. Because of the central role of liver in glucose homeostasis, the aim of the present work was to establish whether $\mathrm{T}_{1} \mathrm{AM}$ affects glucose metabolism in perfused liver and in a hepatocellular carcinoma cell line (HepG2 cells). An additional aim was to determine the uptake and metabolism of $\mathrm{T}_{1} \mathrm{AM}$ in the same preparations.

\section{Materials and methods}

\section{Chemicals}

$\mathrm{T}_{1} \mathrm{AM}, \mathrm{TOAM}, \mathrm{TA} 1, \mathrm{TA} 0$, and their deuterated derivatives used for HPLC-MS/MS were synthesized as described elsewhere (Hart et al. 2006, Miyakawa \& Scanlan 2006, Wood et al 2009). Unless otherwise specified, all other reagents were from Sigma-Aldrich. Solvents for HPLCMS/MS measurements were HPLC grade, and the other chemicals were reagent grade.

\section{Cell culture and treatment}

Human hepatocellular carcinoma cells (HepG2), obtained from American Type Culture Collection (Manassas, VA, USA), were cultured in DMEM supplemented with $10 \%$ (v/v) fetal bovine serum, $1 \mathrm{mM}$ pyruvate, $100 \mathrm{U} / \mathrm{ml}$ penicillin, and $100 \mu \mathrm{g} / \mathrm{ml}$ streptomycin at $37^{\circ} \mathrm{C}$ in a humidified atmosphere containing $5 \% \mathrm{CO}_{2}$ and subcultured before confluence.

The experiments aimed at evaluating hormone uptake and metabolism were carried out as described previously, with minor modifications (Saba et al. 2010). Briefly, cells

Published by Bioscientifica Ltd. 
were seeded into 24 -well plates $\left(8.5 \times 10^{4}\right.$ cells/well $)$ and grown to $80 \%$ confluence. At the start of each experiment, the culture medium was removed and replaced with $0.5 \mathrm{ml}$ of Krebs-Ringer medium $(118 \mathrm{mM} \mathrm{NaCl}, 25 \mathrm{mM}$ $\mathrm{NaHCO}_{3}, 4.5 \mathrm{mM} \mathrm{KCl}, 1.2 \mathrm{mM} \mathrm{KH}_{2} \mathrm{PO}_{4}, 1.2 \mathrm{mM} \mathrm{MgSO}_{4}$, $1.5 \mathrm{mM} \mathrm{CaCl}_{2}, 1 \mathrm{~g} / \mathrm{l}$ glucose, $\mathrm{pH}$ 7.4) and preincubated in a humidified atmosphere of $5 \% \mathrm{CO}_{2}$ at $37^{\circ} \mathrm{C}$ for $30 \mathrm{~min}$. Incubation was initiated by quickly replacing the preincubation medium with $0.5 \mathrm{ml}$ Krebs-Ringer buffer, containing one of the following compounds: $\mathrm{T}_{1} \mathrm{AM}, \mathrm{T}_{3}$, $\mathrm{T}_{4}$ at $1 \mu \mathrm{M}$ concentration. For each of the tested compound, a $1 \mathrm{mM}$ stock solution in DMSO was previously prepared. The plate was returned to a humidified atmosphere of $5 \% \mathrm{CO}_{2}$ at $37{ }^{\circ} \mathrm{C}$, the medium was removed from each well at specific time points ( 5 min to $24 \mathrm{~h}$ ), centrifuged (11 $600 \boldsymbol{g}$ for 2-3 min) to eliminate detached cells, and analyzed by HPLC-MS/MS analysis. The cell plates were then frozen for $24-48 \mathrm{~h}$ and lysed in $0.1 \mathrm{ml}$ $0.1 \mathrm{M} \mathrm{NaOH}$. After $\mathrm{pH}$ neutralization $(0.01 \mathrm{ml} 1.0 \mathrm{~N} \mathrm{HCl})$, the cell lysates were diluted with Krebs-Ringer to a final volume of $0.5 \mathrm{ml}$, centrifuged at $5000 \boldsymbol{g}$ for $10 \mathrm{~min}$, and used for HPLC-MS/MS analysis. As assessed in previous experiments, where cells were removed from the well by scraping in the presence of ice-cold PBS followed by centrifugation at $5000 \mathrm{~g}$ for $10 \mathrm{~min}$, the packed cell volume was on the order of $0.02 \mathrm{ml}$. Therefore, we can assume that during cell lysates preparation $(0.5 \mathrm{ml}$, final volume), the cellular content in the final sample was diluted by about 25 -fold.

Similar experiments were carried out to examine the effect of amine oxidase inhibitor, iproniazid, on $\mathrm{T}_{1} \mathrm{AM}$ metabolism. The cells were preincubated for $30 \mathrm{~min}$ with $0.5 \mathrm{ml}$ Krebs-Ringer buffer supplemented with iproniazid (10 mM stock solution in DMSO to a final concentration of $100 \mu \mathrm{M}$ ) before adding $\mathrm{T}_{1} \mathrm{AM}$.

To assess glucose and ketone body release, HepG2 were seeded into six-well plates $\left(5 \times 10^{5}\right.$ cells/well) and grown to $80 \%$ of confluence with standard medium. Before treatment, the cells were washed twice with PBS and then exposed for $4 \mathrm{~h}$ to exogenous $\mathrm{T}_{1} \mathrm{AM}(0.1,0.5,1$, 5 , and $10 \mu \mathrm{M})$ or TA1 $(0.5$ and $1 \mu \mathrm{M})$ in $1 \mathrm{ml}$ DMEM base, glucose- and phenol red-free, containing $100 \mathrm{U} / \mathrm{ml}$ penicillin, $100 \mu \mathrm{g} / \mathrm{ml}$ streptomycin, and $4 \mathrm{mM}$ L-glutamine, supplemented with $2 \mathrm{mM}$ sodium pyruvate and $20 \mathrm{mM}$ sodium lactate (glucose production buffer; Yoon et al. 2001) at $37^{\circ} \mathrm{C}$ in $5 \% \mathrm{CO}_{2}$. In some experiments, the amine oxidase inhibitor iproniazide $(100 \mu \mathrm{M})$ was also included. Control cells were incubated with DMEM containing DMSO (10-20 $\mu \mathrm{l} /$ well).
To assess free fatty acid (FFA) release, HepG2 were exposed to exogenous $1 \mu \mathrm{M} \mathrm{T}_{1} \mathrm{AM}$ for four or $24 \mathrm{~h}$ in DMEM base (glucose- and phenol red-free), containing $100 \mathrm{U} / \mathrm{ml}$ penicillin, $100 \mu \mathrm{g} / \mathrm{ml}$ streptomycin, and $4 \mathrm{mM}$ glutamine, supplemented with $1 \mathrm{~g} / 1$ glucose and $1 \mathrm{mM}$ sodium pyruvate.

To induce steatosis, HepG2 were exposed to exogenous lipids as described (Di Nunzio et al. 2011, Yao et al. 2011). Cells were incubated with $1 \mu \mathrm{M} \mathrm{T}_{1} \mathrm{AM}$ in DMEM base (glucose- and phenol red-free) containing $100 \mathrm{U} / \mathrm{ml}$ penicillin, $100 \mu \mathrm{g} / \mathrm{ml}$ streptomycin, $4 \mathrm{mM}$ glutamine, $1 \mathrm{~g} / \mathrm{l}$ glucose, $1 \mathrm{mM}$ sodium pyruvate, and supplemented with $1 \mathrm{mM}$ of FFA mixture (2:1 ratio of oleate and palmitate) in $1 \%$ BSA for $24 \mathrm{~h}$ (stock solution of $30 \mathrm{mM}$ FFA was conveniently diluted to $1 \mathrm{mM}$ in culture medium). In each experimental protocol, control cells were incubated with supplemented DMEM-containing DMSO.

Cell culture medium was then collected and glucose, ketone bodies (acetoacetate and 3-hydroxybutyrate), and fatty acid levels were evaluated.

\section{Rat liver perfusion}

This investigation conforms to the Declaration of Helsinki and the Guiding Principles in the Care and Use of Animals. The project was approved by the Animal Care and Use Committee of the University of Pisa.

Male Wistar rats (275-300 g body weight), fed a standard diet, were anesthetized with a mixture of ether and air and the livers were perfused in situ with glucosefree Krebs-Ringer buffer or glucose production buffer equilibrated with a mixture of $\mathrm{O}_{2}(95 \%)$ and $\mathrm{CO}_{2}(5 \%)$ at a constant flow rate of $10 \mathrm{ml} / \mathrm{min}$. The fluid was introduced through a cannula inserted into the portal vein, while a second cannula inserted into the inferior cava vein was used to collect the effluent perfusate. After 10 min washout period and $10 \mathrm{~min}$ perfusion with KrebsRinger buffer alone, $\mathrm{T}_{1} \mathrm{AM}(1 \mu \mathrm{M}$ or $50 \mathrm{nM})$ was added to the non-recirculating buffer, and the liver was perfused for another $40 \mathrm{~min}$, followed by $10 \mathrm{~min}$ of perfusion with Krebs-Ringer buffer alone (Mario et al. 2009). In control experiments, liver was perfused for $60 \mathrm{~min}$ with KrebsRinger buffer alone. During the experiment, samples of the perfusion buffer were collected at $5 \mathrm{~min}$ intervals, and at the end of the experiments the liver was removed and frozen at $-80^{\circ} \mathrm{C}$.

In the experiments to evaluate hormone up-take and metabolism, isolated rat liver was perfused with $50 \mathrm{nM}$ or $1 \mu \mathrm{M} \mathrm{T}_{4}, \mathrm{~T}_{3}$, or $\mathrm{T}_{1} \mathrm{AM}$ in Krebs-Ringer buffer, as described earlier, and tissue concentration was determined after

Published by Bioscientifica Ltd. 
$60 \mathrm{~min}$. HPLC-MS/MS analysis that allowed the simultaneous detection of $\mathrm{T}_{3}, \mathrm{~T}_{4}, \mathrm{~T}_{1} \mathrm{AM}$, and its putative metabolites, namely TOAM, TA0, and TA1, was carried out as described elsewhere (Saba et al. 2010).

\section{Metabolite assays}

Glucose concentration was assessed in $100 \mu \mathrm{l}$ of medium or perfusate with a colorimetric glucose assay kit (Sigma-Aldrich). Ketone bodies were evaluated in the medium or perfusate by enzymatic methods as elsewhere described (Alberti \& Hockaday 1972). Briefly, acetoacetate was determined in a reaction mix containing $0.05 \mathrm{mM} \mathrm{K}_{2} \mathrm{HPO}_{4}(\mathrm{pH} 7), 0.02 \% \mathrm{NADH}$, and $0.25 \mathrm{U} / \mathrm{ml}$ 3-hydroxybutyrate dehydrogenase. The mixture was incubated for $45 \mathrm{~min}$ at $30^{\circ} \mathrm{C}$ and absorbance was read at $340 \mathrm{~nm}$ to evaluate $\mathrm{NADH}$ reduction. 3-Hydroxybutyrate was measured in a reaction mix containing
$0.03 \mathrm{M}$ Tris- $\mathrm{HCl}$ (pH 8.5), 2\% hydrazine, 0.06\% EDTA, $0.02 \% \mathrm{NAD}$, and $0.25 \mathrm{U} / \mathrm{ml}$ 3-hydroxybutyrate dehydrogenase. The mixture was incubated for $45 \mathrm{~min}$ at $30^{\circ} \mathrm{C}$ and absorbance was read at $340 \mathrm{~nm}$ to evaluate $\mathrm{NADH}$ production.

Fatty acid concentration was determined in the cell culture medium with a FFA quantification kit (BioVision Research Product, Malpitas, CA, USA) upon extraction. Fatty acids were extracted by adding $200 \mu \mathrm{l}$ of dichloromethane to $850 \mu \mathrm{l}$ of medium. The mixture was vortexed and spinned at $10000 \boldsymbol{g}$ for $5 \mathrm{~min}$. The organic phase was collected and vacuum dried for $1 \mathrm{~h}$ to remove dichloromethane. Dried lipids were then dissolved in $50 \mu \mathrm{l}$ of assay buffer provided by the kit and used for the assay.

Metabolite concentrations were referred to the total protein content (Bradford 1976) of whole-cell lysates (in HepG2 experiments) or to wet tissue weight (in liver experiments).

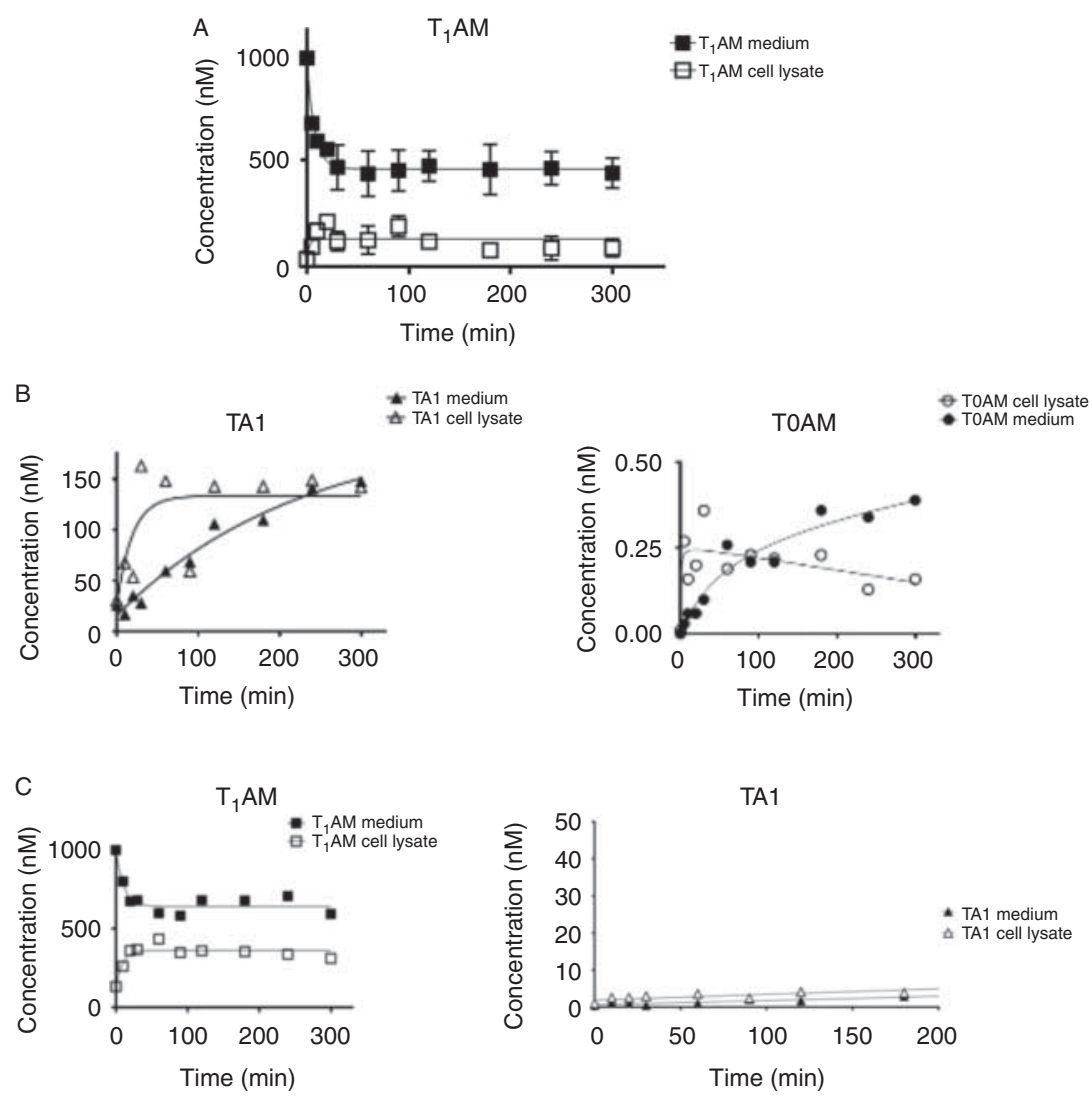

\section{Figure 1}

$\mathrm{T}_{1} \mathrm{AM}$ up-take and metabolism in HepG2 cells (subjected to 20-25 passages in vitro): (A) results of $T_{1} A M$ up-take in HepG2 cell during $6 \mathrm{~h}$ of incubation with $1 \mu \mathrm{M} \mathrm{T} \mathrm{T}_{1} \mathrm{AM}$ (mean \pm S.E.M. of nine biological replicates). (B) Catabolite production during incubation with $1 \mu \mathrm{M} \mathrm{T}_{1} \mathrm{AM}$ : representative results of TOAM and TA1 assay; $(C)$ representative results of $T_{1} A M$ and TA1 assay in (c) 2014 Society for Endocrinology Printed in Great Britain experiments carried out in the presence of $100 \mu \mathrm{M}$ iproniazid. Assays were performed at different time in the incubation medium and in the cell lysate. During preparation, the lysate was diluted $\sim 20$ - to 25 -fold to a final volume of $500 \mu \mathrm{l}$. 


\section{Statistical analysis}

Results are expressed as the mean \pm s.E.M. Differences between groups were analyzed by ANOVA or, when only two groups were involved, by unpaired $t$-test. Regression analysis was performed by linear, exponential, or hyperbolic models, as detailed in the description of each experiment. The threshold of statistical significance was set at $P<0.05$. GraphPad Prism version 6.0 for Windows (GraphPad Software, San Diego, CA, USA) was used for data processing and statistical analysis.

\section{Results}

\section{$T_{1} A M$ uptake and catabolism in HepG2 cells and in perfused rat liver}

When cells were exposed to $1 \mu \mathrm{M} \mathrm{T}_{1} \mathrm{AM}$, its concentration in the incubation medium decreased exponentially, while lysate $\mathrm{T}_{1} \mathrm{AM}$ increased, reaching a steady state after about $10 \mathrm{~min}$ (Fig. 1A). In these experiments, incubation medium volume was $500 \mu \mathrm{l}$, while the original volume of cell lysate was on the order of 20-25 $\mu \mathrm{l}$, and the latter was diluted to a final volume of $500 \mu \mathrm{l}$ to facilitate processing and assay. Steady-state concentrations were close to 500 and $150 \mathrm{nM}$ in the incubation medium and in diluted cell lysate respectively (Fig. 1A). Taking into account the dilution factor, the actual steady-state cellular concentration can be estimated to average about $3-4 \mu \mathrm{M}$, exceeding medium concentration by over six- to eightfold. The overall recovery of $\mathrm{T}_{1} \mathrm{AM}$ was on the order of $65-70 \%$ (500 pmol were added and the final amounts detected in incubation medium and in cell lysate averaged $\sim 250$ and 75 pmol respectively).
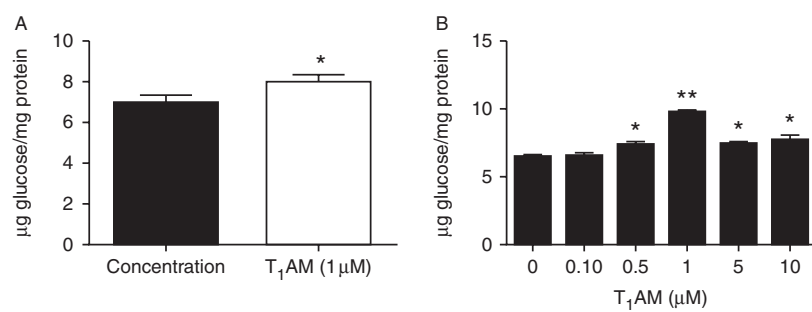

Figure 2

Glucose and ketone body $(K B)$ production in HepG2 cell cultures that were incubated for $4 \mathrm{~h}$ in glucose production buffer as described in Materials and methods. Glucose or KB concentration was assayed in the medium. Results are expressed as mean \pm S.E.M. and are normalized to the total cell protein content determined in cell lysates. (A) Glucose concentration after incubation with $1 \mu \mathrm{M} \mathrm{T}_{1} \mathrm{AM}$ ( $n=9$ per group). (B) A dose-response curve was obtained using $0.1,0.5,1,5,10 \mathrm{nmol} / \mathrm{ml}$ of $T_{1} A M$, corresponding to 0.1 ,
$\mathrm{T}_{1} \mathrm{AM}$ adhesion to cell culture plates, as determined by carrying out the experiment in the absence of cells, was limited, accounting only for about $10 \%$ decrease in $\mathrm{T}_{1} \mathrm{AM}$ concentration. Additional experiments were also carried out at $4{ }^{\circ} \mathrm{C}$, and the rate constant of the exponential decay decreased from $0.052 \pm 0.006 / \mathrm{min}$ to $0.025 \pm 0.004 / \mathrm{min}$ $(P<0.01)$, suggesting that active biochemical process are involved in this phenomenon.

Medium and lysate were also assayed for $\mathrm{T}_{1} \mathrm{AM}$ catabolites. TA1 accumulated over time both in lysate and in medium, reaching a concentration of about $140 \mathrm{nM}$ in both compartments after $240 \mathrm{~min}$ (due to lysate dilution, this corresponds to an estimated cellular concentration of $2.8-3.5 \mu \mathrm{M})$. TOAM was detected at very low concentration ( $<0.5 \mathrm{nM}$ ) (Fig. 1B), while TA0 was not revealed (data not shown). Overall catabolite production accounted for about $30 \%$ of $\mathrm{T}_{1} \mathrm{AM}$ administration.

Experiments were repeated in the presence of the amine oxidase inhibitor iproniazid, and in these conditions $\mathrm{T}_{1} \mathrm{AM}$ recovery averaged 99\%, because after 240 min incubation medium and lysate concentrations averaged 700 and $300 \mathrm{nM}$, respectively, while TA1 production was almost abolished (Fig. 1C) and TOAM was not significantly modified (data not shown).

By comparison, similar experiments were performed by incubating HepG2 cells with $\mathrm{T}_{3}$ or $\mathrm{T}_{4}$. As observed with $\mathrm{T}_{1} \mathrm{AM}$, lysate concentrations increased while medium concentrations decreased exponentially, until a steady state was obtained after about $120 \mathrm{~min}$. At the steady state, medium concentrations averaged $651 \pm 73$ and $413 \pm$ $91 \mathrm{nM}$ for $\mathrm{T}_{3}$ and $\mathrm{T}_{4}$ respectively. The corresponding lysate concentrations were $135 \pm 59$ and $343 \pm 137 \mathrm{nM}$ respectively. The overall recovery was close to $80 \%$ for $\mathrm{T}_{3}$ and $\mathrm{T}_{4}$.
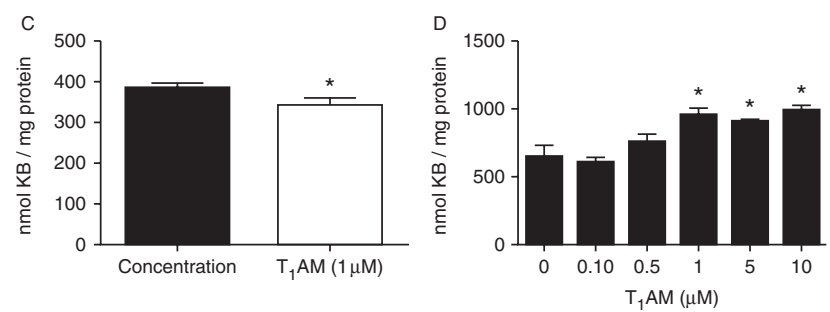

$0.5,1,5$, and $10 \mu \mathrm{M}$ concentrations ( $n=3$ in each case). ( $C$ and $D) K B$ production: (A and C) $1 \mu \mathrm{M} \mathrm{T}_{1} \mathrm{AM}$ administered to cells which underwent $>30$ in vitro passages $(n=9)$, while in $(B$ and $D)$ a dose-response curve $(n=3)$ was obtained in cells which underwent $<20$ in vitro passages. See text for further details. ${ }^{*} P<0.05, * * P<0.01$ by ANOVA or unpaired $t$-test, as appropriate.

Published by Bioscientifica Ltd. 
$\mathrm{T}_{1} \mathrm{AM}, \mathrm{T}_{3}$, and $\mathrm{T}_{4}$ uptake were also investigated in perfused rat liver. After $40 \mathrm{~min}$ of perfusion with $50 \mathrm{nM}$ or $1 \mu \mathrm{M} \mathrm{T}_{1} \mathrm{AM}$, tissue concentration averaged $87.2 \pm 22.0$ and $1013.8 \pm 312.5 \mathrm{pmol} / \mathrm{g}$, respectively, vs a control value of $7.1 \pm 4.2 \mathrm{pmol} / \mathrm{g}$. Among putative catabolites, only TOAM was detected in the liver homogenate at concentrations approximately one order of magnitude lower than $\mathrm{T}_{1} \mathrm{AM}$. In this model, $\mathrm{T}_{1} \mathrm{AM}$ uptake was lower than $\mathrm{T}_{3}$ and $\mathrm{T}_{4}$ uptake, because after $40 \mathrm{~min}$ of perfusion with $50 \mathrm{nM} \mathrm{T}$ or $\mathrm{T}_{4}$ their tissue concentrations averaged 853.6 and $1531.2 \mathrm{pmol} / \mathrm{g}$, respectively, vs control values of 3.9 and $15.5 \mathrm{pmol} / \mathrm{g}$. If perfusate $\mathrm{T}_{3}$ and $\mathrm{T}_{4}$ concentrations were raised to $1 \mu \mathrm{M}$, tissue concentrations after $40 \mathrm{~min}$ of perfusion averaged 2.14 and $3.90 \mu \mathrm{mol} / \mathrm{g}$ respectively. In the latter experiments, the assay of $\mathrm{T}_{3}$ and $\mathrm{T}_{4}$ in the perfusion buffer confirmed that over $90 \%$ of infused hormones were taken up and stored in the tissue.

Notably, perfusion with $\mathrm{T}_{3}$ or $\mathrm{T}_{4}$ was not associated with significant increase in tissue $\mathrm{T}_{1} \mathrm{AM}$, nor was perfusion with $\mathrm{T}_{1} \mathrm{AM}$ was not associated with any significant change in tissue $\mathrm{T}_{3}$ or $\mathrm{T}_{4}$ (data not shown).

\section{Metabolite assays}

In HepG2 cells cultured in glucose production buffer (Fig. 2A), incubation with $1 \mu \mathrm{M} \mathrm{T}_{1} \mathrm{AM}$ induced $\sim 25 \%$ increase in glucose production $(P<0.01)$. In other experiments, the dose dependence of this effect was investigated (Fig. 2B): the estimated $\mathrm{EC}_{50}$ was $0.84 \mu \mathrm{M}$, but at 5 or $10 \mu \mathrm{M} \mathrm{T}_{1} \mathrm{AM}$ the stimulation of glucose production decreased, yielding a bell-shaped dose-response curve.

More complex findings were obtained with regard to ketone body production. Baseline ketone body production and the response to $\mathrm{T}_{1} \mathrm{AM}$ apparently depended on the number of passages performed in vitro. Using cells which underwent $>30$ passages in vitro, treatment with $1 \mu \mathrm{M}$ $\mathrm{T}_{1} \mathrm{AM}$ produced a slight (11\%) but significant decrease in ketone body release (Fig. 2C), chiefly accounted for by decreased acetoacetate release $(252.4 \pm 10.5$ vs $286.8 \pm$ $7.2 \mathrm{nmol} / \mathrm{mg}$ protein, $P<0.05$ ), while no significant effect was detected using 0.1 or $10 \mu \mathrm{M} \mathrm{T} \mathrm{T}_{1} \mathrm{AM}$ (data not shown). However, when we took care to use cells that underwent no more than 20 passages, we observed that baseline ketone body production was higher (on the order of $630 \mathrm{nmol} / \mathrm{mg}$ proteins), and under these conditions $\mathrm{T}_{1} \mathrm{AM}$ produced a dose-dependent stimulation of ketone body release, with $\mathrm{EC}_{50}$ on the order of $1.12 \mu \mathrm{M}$ (Fig. 2D).

In the presence of $100 \mu \mathrm{M}$ iproniazid, the increase in glucose production induced by $1 \mu \mathrm{M} \mathrm{T} \mathrm{T}_{1} \mathrm{AM}$ was dampened (9\%) and did not reach the threshold of statistical
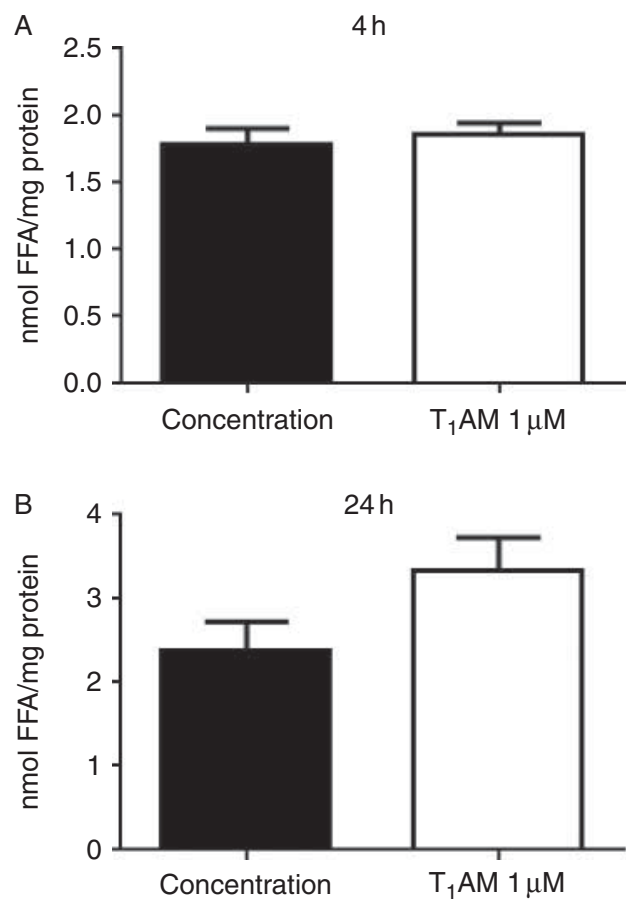

Figure 3

Free fatty acid (FFA) production in HepG2 cell cultures that were incubated for $4 \mathrm{~h}(\mathrm{~A})$ or $24 \mathrm{~h}(\mathrm{~B})$ in DMEM medium as described in Materials and methods. Results are expressed as mean \pm S.E.M. of nine biological replicates and are normalized to the total cell protein content determined in cell lysates. Differences between groups were not statistically significant (unpaired $t$-test)

significance $(5.99 \pm 0.17$ vs $6.53 \pm 0.31 \mu \mathrm{g} / \mathrm{mg}$ protein in cell lysate, $P=\mathrm{NS}$ ). We also tested the effect of TA1, the major $\mathrm{T}_{1} \mathrm{AM}$ catabolite, and, at $500 \mathrm{nM}$ or $1 \mu \mathrm{M}$ concentration, it did not affect either glucose or ketone body release. Notably, cellular uptake of TA1 was substantially lower than that observed with $\mathrm{T}_{1} \mathrm{AM}(15$ vs $60 \%)$.

In the presence of exogenous glucose, $\mathrm{T}_{1} \mathrm{AM}$ did not produce any change in fatty acid production after 4 or $24 \mathrm{~h}$ of incubation (Fig. 3A and B), although at the later time point there was a slight increase that did not reach the threshold of statistical significance $(\mathrm{P}=0.088)$. Under conditions promoting steatosis, i.e. with supplementation of exogenous glucose and fatty acid mixture, after $24 \mathrm{~h}$ $\mathrm{T}_{1} \mathrm{AM}$ did not affect FFA concentration, while glucose concentration was increased $(P<0.01)$, suggesting increased production and/or decreased consumption (Fig. 4A and B).

Liver perfusion with glucose production buffer in the presence of $1 \mu \mathrm{M} \mathrm{T}$ 1 AM (Fig. 5) also showed a significant increase in glucose production (Fig. $5 \mathrm{~A}, P<0.05$ ) that was associated with increased ketone body release (Fig. 5B, $P<0.01$ ), largely accounted for by increased

Published by Bioscientifica Ltd. 
A

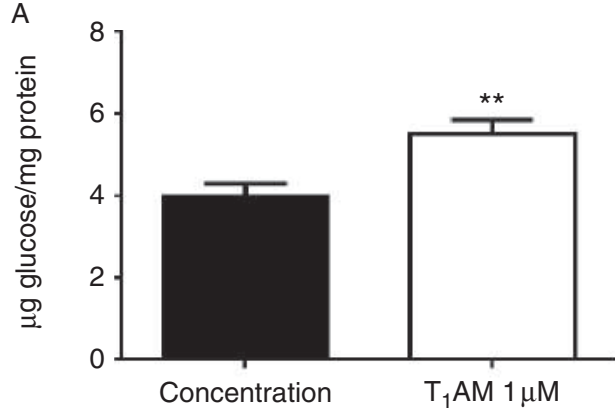

B

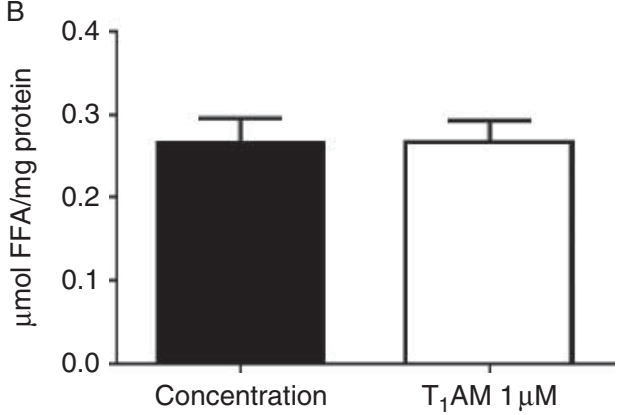

\section{Figure 4}

Glucose (A) and fatty acids (B) concentration in HepG2 cell cultures after incubation for $24 \mathrm{~h}$ in conditions promoting steatosis, i.e. DMEM medium containing $1 \mathrm{mM}$ free fatty acids $1 \mathrm{mM}$ and $1 \mathrm{~g} / \mathrm{l}$ glucose. Results are expressed as mean \pm s.E.M. of nine biological replicates and are normalized to the total cell protein content determined in cell lysates. ${ }^{*} P<0.01$ by unpaired $t$-test.

3-hydroxybutyrate release $(246.0 \pm 21.04$ vs $153.3 \pm$ $11.81 \mathrm{nmol} / \mathrm{min}$ per $\mathrm{g}, P<0.01)$.

Infusion with Krebs-Ringer buffer did not produce any significant change in metabolite release (glucose: $0.24 \pm 0.17$ vs $0.29 \pm 0.02 \mathrm{mg} / \mathrm{min}$ per g, $P=\mathrm{NS}$; ketone bodies $40.1 \pm 4.9$ vs $35.1 \pm 3.0 \mathrm{nmol} / \mathrm{min}$ per $\mathrm{g}, n=8-9$ ). A few experiments $(n=2)$ were also carried out in livers obtained from $4 \mathrm{~h}$ fasted rats, and a $26 \%$ increase in the release of ketone bodies was observed $(231 \pm 22$ vs $175 \pm$ $25 \mathrm{nmol} / \mathrm{min}$ per g), while glucose release was not affected $(0.28 \pm 0.06$ vs $0.28 \pm 0.05 \mathrm{mg} / \mathrm{min}$ per g).

\section{Discussion}

In this investigation, we observed that $\mathrm{T}_{1} \mathrm{AM}$, such as $\mathrm{T}_{3}$ and $\mathrm{T}_{4}$, can be taken up and accumulated in hepatocytes. In HepG2 cell culture, these compounds were quickly absorbed because their presence was detected in cell lysate after a few minutes of infusion. At the steady state, estimated cellular concentration exceeded medium concentration by about six- to eightfold. These results are in agreement with previous observations performed in cardiomyocytes (Saba et al. 2010) and in FRTL-5 thyroid cells (Agretti et al. 2011), and they are consistent with the results obtained in perfused liver, where tissue concentration was higher than perfusate concentration. In this model, the ratio between tissue and perfusate concentration was lower than the lysate:medium ratio observed in cell cultures, but it should be considered that $\mathrm{T}_{1} \mathrm{AM}$ is likely to be taken up and catabolized by vascular and interstitial cells, and that it undergoes biliary excretion (Chiellini et al. 2012).

In HepG 2 cells, $\mathrm{T}_{1} \mathrm{AM}$ recovery was on the order of $70 \%$. Most of the balance was accounted for by oxidative deamination, yielding the thyroacetic derivative TA1 that was detectable in cell lysate and medium within a few minutes. Although D1 deiodinase has been reported to be expressed in HepG2 cells (Jakobs et al. 2002), TOAM production was minimal, probably because of the absence of D3 deiodinase and/or of essential cofactors for deiodination or decarboxylation, while it was greater in perfused liver, where it appears to be more relevant than oxidative deamination. We cannot, however, exclude that additional metabolic pathways may be active, particularly conjugation to sulfate and glucuronide (Hackenmueller \& Scanlan 2012), because the corresponding derivatives could not be tested by the present method.

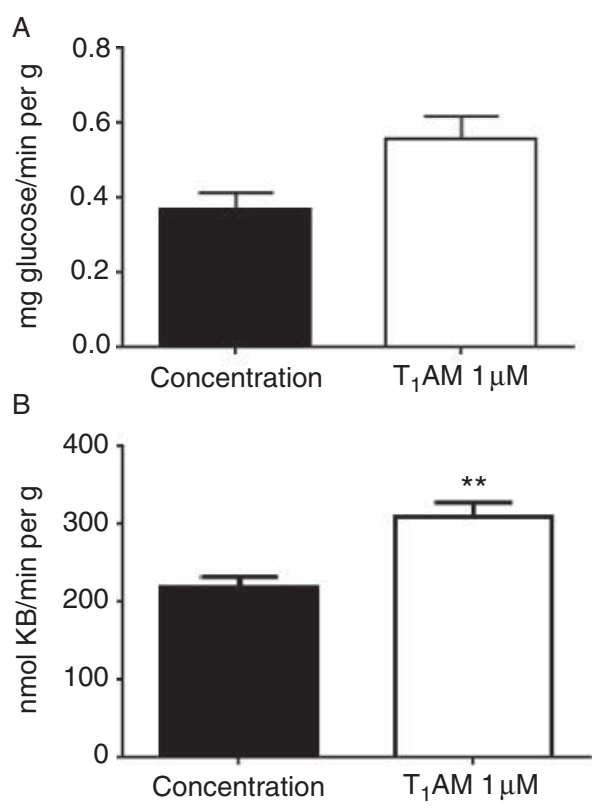

Figure 5

Glucose (A) and ketone body (KB) (B) release by livers perfused with $1 \mu \mathrm{M}$ $T_{1} A M$ in glucose production buffer. Glucose and $K B$ concentrations were determined in the perfusate every $5 \mathrm{~min}$ for a total period of $40 \mathrm{~min}$, and the average release rate was calculated, as described in Materials and methods. Results are expressed as mean \pm s.E.M. of the three experiments and are normalized to tissue wet weight. $* * P<0.01$ by unpaired $t$-test.

Published by Bioscientifica Ltd. 
It should be stressed that about $50 \%$ of administered $\mathrm{T}_{1} \mathrm{AM}, \mathrm{T}_{3}$, or $\mathrm{T}_{4}$, was detected in cell lysate after $2 \mathrm{~h}$ of infusion. As a consequence at the steady state the estimated cellular concentration of $\mathrm{T}_{3}, \mathrm{~T}_{4}$, and $\mathrm{T}_{1} \mathrm{AM}$ was significantly higher than medium concentration. This suggests the existence of specific binding sites and/or transport pathways for $\mathrm{T}_{1} \mathrm{AM}$ and thyroid hormones.

The molecular mechanism by which TOAMs are taken up is still controversial. Eight potential transporters belonging to the solute carrier family have been tentatively identified (Ianculescu et al. 2009), although their affinity and sodium-independence did not seem to be consistent with the characteristics of $\mathrm{T}_{1} \mathrm{AM}$ uptake (Saba et al. 2010). Recently it has been reported that $T_{1} A M$ is largely bound to apolipoprotein B-100 (apo-B100), the protein component of LDLs (Roy et al. 2012). This could be a potential vehicle to transport $\mathrm{T}_{1} \mathrm{AM}$ and other TOAMs into cells which expressed the receptor for $\mathrm{LDL}$, even though this is unlikely to contribute to our results, because in our experiments the standard growth medium supplemented with fetal bovine serum was replaced with other media, namely Krebs buffer or glucose production buffer, which do not contain lipoproteins. In any case, the kinetics of $\mathrm{T}_{1} \mathrm{AM}$ removal from the incubation medium was significantly lower at $4{ }^{\circ} \mathrm{C}$, suggesting the presence of active transport mechanisms.

The primary aim of this work was to establish whether $\mathrm{T}_{1} \mathrm{AM}$ may directly stimulate hepatic glucose production. If adequate substrates for gluconeogenesis were provided, $\mathrm{T}_{1} \mathrm{AM}$ increased glucose production in two different experimental models, namely cultured HepG2 cells and in situ perfused rat liver. So consistent results were obtained in different experimental models, which also investigate different time scales, because the former was a subchronic and the latter an acute model. We conclude that modulation of hepatic metabolism may contribute to the hyperglycemic effect reported after administration of exogenous $\mathrm{T}_{1} \mathrm{AM}$ (Regard et al. 2007, Klieverik et al. 2009, Manni et al. 2012), which had previously been attributed only to modulation of insulin and/or glucagone secretion.

In HepG2 cells, the $\mathrm{EC}_{50}$ for the effect on gluconeogenesis was in the submicromolar range, and in perfused liver experiments a significant effect was observed with infusion of $1 \mu \mathrm{M} \mathrm{T}_{1} \mathrm{AM}$, resulting in tissue concentration on the order of $1000 \mathrm{pmol} / \mathrm{g}$. It is not easy to discuss the potential physiological relevance of these observations, as there is still some uncertainty about the physiological levels of $\mathrm{T}_{1} \mathrm{AM}$. In humans, using an immunological assay (Hoefig et al. 2011), the plasma concentrations were reported on the order of $66 \mathrm{nM}$, while plasma $\mathrm{T}_{1} \mathrm{AM}$ concentration measured by a mass spectrometry-based assay was about 200-fold lower (Galli et al. 2012). As $\mathrm{T}_{1} \mathrm{AM}$ binds with high affinity to apo-B100 (Roy et al. 2012), it has been hypothesized that these different techniques estimate total and free $\mathrm{T}_{1} \mathrm{AM}$ respectively. However, $\mathrm{T}_{1} \mathrm{AM}$ is known to be concentrated in tissues, as discussed above, and we have previously reported that its liver content in rat in vivo was on the order of $90 \mathrm{pmol} / \mathrm{g}$ (Saba et al. 2010). If we rely on this value, then we may suggest that infusion of exogenous $1 \mu \mathrm{M} \mathrm{T}_{1} \mathrm{AM}$ raised liver concentration to a value that was one order of magnitude greater than the physiological concentration, after the depletion presumably occurring during prolonged perfusion with $\mathrm{T}_{1} \mathrm{AM}$-free buffer (after over 60 min of perfusion 'control' values were close to $1 \mathrm{pmol} / \mathrm{g}$ ). Further experiments will be necessary to clarify these important issues.

The effect of $\mathrm{T}_{1} \mathrm{AM}$ on gluconeogenesis may show a bell-shaped dose-response curve, because the response of HepG2 was reduced at the highest concentration tested $(10 \mu \mathrm{M})$. This is not surprising, because other functional effects of $\mathrm{T}_{1} \mathrm{AM}$, particularly on feeding and behavior, are also biphasic (Dhillo et al. 2009, Hettinger et al. 2010, Manni et al. 2012). Consistent with this interpretation, the response to $1 \mu \mathrm{M} \mathrm{T}_{1} \mathrm{AM}$ decreased in the presence of iproniazid, which inhibits its deamination to TA1, while we did not obtain any significant response after administration of exogenous TA1, whose cellular uptake was very low.

Another effect attributed to $\mathrm{T}_{1} \mathrm{AM}$ is the stimulation of lipid catabolism, with a shift from glucose to fatty acid as energy source (Braulke et al. 2008, Haviland et al. 2013). We observed a similar effect in the perfused liver model, because $\mathrm{T}_{1} \mathrm{AM}$ induced an increase in the release of ketone bodies. The results obtained in the HepG2 model were more complex, and in a subset of cells showing low values of baseline ketone body production $\mathrm{T}_{1} \mathrm{AM}$ reduced ketogenesis.

The different timing of these two experimental models might partly account for this discrepancy, because in the conscious mouse $\mathrm{T}_{1} \mathrm{AM}$-induced stimulation of lipid catabolism was also time dependent (Haviland et al. 2013). Alternatively, it might be suggested that energy production by HepG2 cells, which are known to have limited ketogenic capability (Vilà-Brau et al. 2011), may be significantly dependent on pyruvate and amino acid catabolism, so that pyruvate shift toward gluconeogenesis would cause less acetyl-CoA to be available for ketogenesis. Notably, in HepG2 cells no significant effect was apparent on fatty acid production.

Published by Bioscientifica Ltd. 
In conclusion, we observed that $\mathrm{T}_{1} \mathrm{AM}$ is actively accumulated in hepatocytes, where at concentrations in the micromolar range it is able to stimulate gluconeogenesis and to stimulate ketogenesis, provided that adequate energy substrates are available. These effects are independent from hormonal changes and might have physiological and pathophysiological importance. It would also been interesting to investigate whether $\mathrm{T}_{1} \mathrm{AM}$ may contribute to the metabolic effects usually attributed to thyroid hormone and/or to the metabolic abnormalities observed in hypothyroidism, a condition in which tissue and plasma $\mathrm{T}_{1} \mathrm{AM}$ levels have been reported to be decreased (Galli et al. 2012, Hackenmueller et al. 2012).

\section{Declaration of interest}

The authors declare that there is no conflict of interest that could be perceived as prejudicing the impartiality of the research reported.

\section{Funding}

This work was supported by a PRIN Italian research grant (Research Projects of National Interest) awarded to R Z in 2008.

\section{Author contribution statement}

S G and G C designed and carried out cell culture experiments and metabolic assays. S F performed the ex vivo experiments on liver. A S carried out mass spectrometry measurements. $\mathrm{R} Z$ designed and supervised the experimental work and wrote the manuscript.

\section{References}

Agretti P, De Marco G, Russo L, Saba A, Raffaelli A, Marchini M, Chiellini G, Grasso L, Pinchera A, Vitti P et al. 2011 3-Iodothyronamine metabolism and functional effects in FRTL5 thyroid cells. Journal of Molecular Endocrinology 47 23-32. (doi:10.1530/JME-10-0168)

Alberti KGMM \& Hockaday TDR 1972 Rapid blood ketone body estimation in the diagnosis of diabetic ketoacidosis. BMJ 2 565-568. (doi:10.1136/ bmj.2.5813.565)

Bradford MM 1976 A rapid and sensitive method for the quantification of microgram quantities of protein utilizing the principle of protein-dye binding. Analytical Biochemistry 72 248-254. (doi:10.1016/00032697(76)90527-3)

Braulke LJ, Klingenspor M, DeBarber A, Tobias SC, Grandy DK, Scanlan TS \& Heldmaier G 2008 3-Iodothyronamine: a novel hormone controlling the balance between glucose and lipid utilisation. Journal of Comparative Physiology B 178 167-177. (doi:10.1007/s00360007-0208-x)

Chiellini G, Frascarelli S, Ghelardoni S, Carnicelli V, Tobias SC, DeBarber A, Brogioni S, Ronca-Testoni S, Cerbai E, Grandy DK et al. 2007 Cardiac effects of 3-iodothyronamine: a new aminergic system modulating cardiac function. FASEB Journal 21 1597-1608. (doi:10.1096/fj.06$7474 \mathrm{com})$

Chiellini G, Erba P, Carnicelli V, Manfredi C, Frascarelli S, Ghelardoni S, Mariani G \& Zucchi R 2012 Distribution of exogenous $\left[{ }^{125} \mathrm{I}\right]-3$ iodothyronamine in mouse in vivo: relationship with trace amine-associated receptors. Journal of Endocrinology 213 223-230. (doi:10.1530/JOE-12-0055)

Cumero S, Fogolari F, Domenis R, Zucchi R, Mavelli I \& Contessi S 2012 Mitochondrial F(0) F(1)-ATP synthase is a molecular target of 3-iodothyronamine, an endogenous metabolite of thyroid hormone. British Journal of Pharmacology 166 2331-2347. (doi:10.1111/j.14765381.2012.01958.x)

Dhillo WS, Bewick GA, White NE, Gardiner JV, Thompson EL, Bataveljic A, Murphy KG, Roy D, Patel NA, Scutt JN et al. 2009 The thyroid hormone derivative 3-iodothyronamine increases food intake in rodents. Diabetes, Obesity and Metabolism 11 251-260. (doi:10.1111/j.1463-1326. 2008.00935.x)

Di Nunzio M, Valli V \& Bordoni A 2011 Pro- and anti-oxidant effects of polyunsaturated fatty acid supplementation in HepG2 cells. Prostaglandins, Leukotrienes and Essential Fatty Acids 85 121-127. (doi:10.1016/j.plefa.2011.07.005)

Galli E, Marchini M, Saba A, Berti S, Tonacchera M, Vitti P, Scanlan TS, Iervasi G \& Zucchi R 2012 Detection of 3-iodothyronamine in human patients: a preliminary study. Journal of Clinical Endocrinology and Metabolism 97 E69-E74. (doi:10.1210/jc.2011-1115)

Hackenmueller SA \& Scanlan TS 2012 Identification and quantification of 3-iodothyronamine metabolites in mouse serum using liquid chromatography-tandem mass spectrometry. Journal of Chromatography 1256 89-97. (doi:10.1016/j.chroma.2012.07.052)

Hackenmueller SA, Marchini M, Saba A, Zucchi R \& Scanlan TS 2012 Biosynthesis of 3-iodothyronamine (T1AM) is dependent on the sodium-iodide symporter and thyroperoxidase but does not involve extrathyroidal metabolism of $\mathrm{T}_{4}$. Endocrinology 153 5659-5667. (doi:10.1210/en.2012-1254)

Hart ME, Suchland KL, Miyakawa M, Bunzow JR, Grandy DK \& Scanlan TS 2006 Trace amine-associated receptor agonists: synthesis and evaluation of thyronamines and related analogues. Medicinal Chemistry 49 1101-1112. (doi:10.1021/jm0505718)

Haviland JA, Reiland H, Butz DE, Tonelli M, Porter WP, Zucchi R, Scanlan TS, Chiellini G \& Assadi-Porter FM 2013 NMR-based metabolomics and breath studies show lipid and protein catabolism during low dose chronic T1 AM treatment. Obesity 21 2538-2544. (doi:10.1002/oby.20391)

Hettinger BD, Schuff K, Marks D \& Scanlan TS 2010 3-Iodothyronamine (T1AM) causes weight loss in mice via reduction in food consumption. 14th International Thyroid Congress, Paris, France. Abstract OC-141.

Hoefig CS, Köhrle J, Brabant G, Dixit K, Yap B, Strasburger CJ \& Wu Z 2011 Evidence for extrathyroidal formation of 3-iodothyronamine in humans as provided by a novel monoclonal antibodybased chemiluminescent serum immunoassay. Journal of Clinical Endocrinology and Metabolism 96 1864-1872. (doi:10.1210/jc.2010-2680)

Ianculescu AG, Giacomini KM \& Scanlan TS 2009 Identification and characterization of 3-iodothyronamine intracellular transport. Endocrinology 150 1991-1999. (doi:10.1210/en.2008-1339)

Jakobs TC, Mentrup B, Schmutzler C, Dreher I \& Köhrle J 2002 Proinflammatory cytokines inhibit the expression and function of human type I 5'-deiodinase in HepG2 hepatocarcinoma cells. European Journal of Endocrinology 146 559-566. (doi:10.1530/eje.0.1460559)

Klieverik LP, Janssen SF, van Riel A, Foppen E, Bisschop PH, Serlie MJ, Boelen A, Ackermans MT, Sauerwein HP, Fliers E et al. 2009 Thyroid hormone modulates glucose production via a sympathetic pathway from the hypothalamic paraventricular nucleus to the liver. PNAS 106 5966-5971. (doi:10.1073/pnas.0805355106)

Liggett SB 2004 The two-timing thyroid. Nature Medicine 10 582-583. (doi:10.1038/nm0604-582)

Manni ME, De Siena G, Saba A, Marchini M, Dicembrini I, Bigagli E, Cinci L, Lodovici M, Chiellini G, Zucchi R et al. 2012 3-Iodothyronamine: a modulator of the hypothalamus-pancreas-thyroid axes in mice. British Journal of Pharmacology 166 650-658. (doi:10.1111/j.1476-5381. 2011.01823.x) 
Manni ME, De Siena G, Saba A, Marchini M, Landucci E, Gerace E, Zazzeri M, Musilli C, Pellegrini-Giampietro D, Matucci R et al. 2013 Pharmacological effects of 3-iodothyronamine (T1AM) in mice include facilitation of memory acquisition and retention and reduction of pain threshold. British Journal of Pharmacology 168 354-362. (doi:10.1111/ j.1476-5381.2012.02137.x)

Mario EG, Leonardo ES, Bassoli BK, Cassolla P, Borba-Murad GR, Bazotte RB $\&$ de Souza HM 2009 Investigation of the acute effect of leptin on the inhibition of glycogen catabolism by insulin in rat liver perfused in situ. Pharmacological Reports 61 319-324. (doi:10.1016/S17341140(09)70038-6)

Miyakawa M \& Scanlan TS 2006 Synthesis of $\left[{ }^{125} \mathrm{I}\right]-,\left[{ }^{2} \mathrm{H}\right]-$, and $\left[{ }^{3} \mathrm{H}\right]$-labelled 3-iodothyronamine (T1AM). Synthetic Communications 36891. (doi:10.1080/00397910500466074)

Piehl S, Hoefig CS, Scanlan TS \& Köhrle J 2011 Thyronamines - past, present, and future. Endocrine Reviews 2 64-80. (doi:10.1210/ er.2009-0040)

Regard JB, Kataoka H, Cano DA, Camerer E, Yin L, Zheng YW, Scanlan TS, Hebrok M \& Coughlin SR 2007 Probing cell type-specific functions of Gi in vivo identifies GPCR regulators of insulin secretion. Journal of Clinical Investigation 117 4034-4043. (doi:10.1172/JCI32994)

Roy G, Placzek E \& Scanlan TS 2012 ApoB-100-containing lipoproteins are major carriers of 3-iodothyronamine in circulation. Journal of Biological Chemistry 287 1790-1800. (doi:10.1074/jbc.M111.275552)

Saba A, Chiellini G, Frascarelli S, Marchini M, Ghelardoni S, Raffaelli A, Tonacchera M, Vitti P, Scanlan TS \& Zucchi R 2010 Tissue distribution and cardiac metabolism of 3-iodothyronamine. Endocrinology 151 5063-5073. (doi:10.1210/en.2010-0491)

Scanlan TS, Suchland KL, Hart ME, Chiellini G, Huang Y, Kruzich PJ, Frascarelli S, Crossley DA, Bunzow JR, Ronca-Testoni S et al. 2004
3-Iodothyronamine is an endogenous and rapid-acting derivative of thyroid hormone. Nature Medicine 10 638-642. (doi:10.1038/ nm1051)

Snead AN, Santos MS, Seal RP, Miyakawa M, Edwards RH \& Scanlan TS 2007 Thyronamines inhibit plasma membrane and vesicular monoamine transport. ACS Chemical Biology 2 390-398. (doi:10.1021/cb700057b)

Venditti P, Napolitano G, Di Stefano L, Chiellini G, Zucchi R, Scanlan TS \& Di Meo S 2011 Effects of the thyroid hormone derivatives 3-iodothyronamine and thyronamine on rat liver oxidative capacity. Molecular and Cellular Endocrinology 341 55-62. (doi:10.1016/j.mce. 2011.05.013)

Vilà-Brau A, De Sousa-Coelho AL, Mayordomo C, Haro D \& Marrero PF 2011 Human HMGCS2 regulates mitochondrial fatty acid oxidation and FGF21 expression in HepG2 cell line. Journal of Biological Chemistry 286 20423-20430. (doi:10.1074/jbc.M111.235044)

Weatherman RV 2007 A triple play for thyroid hormone. ACS Chemical Biology 2 377-379. (doi:10.1021/cb700104v)

Wood WJ, Geraci T, Nilsen A, DeBarber AE \& Scanlan TS 2009 Iodothyronamines are oxidatively deaminated to iodothyroacetic acids in vivo. Chembiochem 10 361-365. (doi:10.1002/cbic.200800607)

Yao HR, Liu J, Plumeri D, Cao YB, He T, Lin L, Li Y, Jiang YY, Li J \& Shang J 2011 Lipotoxicity in HepG2 cells triggered by free fatty acids. American Journal of Translational Research 3 284-291.

Yoon JC, Puigserver P, Chen G, Donovan J, Wu Z, Rhee J, Adelmant G, Stafford J, Kahn CR, Granner DK et al. 2001 Control of hepatic gluconeogenesis through the transcriptional coactivator PGC-1. Nature 413 131-138. (doi:10.1038/35093050)

Zucchi R, Chiellini G, Scanlan TS \& Grandy DK 2006 Trace amineassociated receptors and their ligands. British Journal of Pharmacology 49 967-978. (doi:10.1038/sj.bjp.0706948)

Received in final form 29 January 2014 Accepted 31 January 2014
(C) 2014 Society for Endocrinology Printed in Great Britain 